\title{
Implications of Loyalty Program Membership and Service Experiences for Customer Retention and Value
}

\author{
Ruth N. Bolton \\ University of Oklahoma \\ P. K. Kannan \\ Matthew D. Bramlett
}

University of Maryland

Companies that offer loyalty reward programs believe that their programs have a long-run positive effect on customer evaluations and behavior. However, if loyalty rewards programs increase relationship durations and usage levels, customers will be increasingly exposed to the complete spectrum of service experiences, including experiences that may cause customers to switch to another service provider. Using cross-sectional, time-series data from a worldwide financial services company that offers a loyalty reward program, this article investigates the conditions under which a loyalty rewards program will have a positive effect on customer evaluations, behavior, and repeat purchase intentions. The results show that members in the loyalty reward program overlook or discount negative evaluations of the company vis-à-vis competition. One possible reason could be that members of the loyalty rewards program perceive that they are getting better quality and service for their price or, in other words, "good value."

Organizations have long sought to reward the loyalty of preferred customers with enhanced services or price discounts. Recently, loyalty rewards programs have become prevalent across a variety of service industries. For example,

Journal of the Academy of Marketing Science.

Volume 28, No. 1, pages 95-108.

Copyright $\odot 2000$ by Academy of Marketing Science.
- Reward programs based on service usage levels (i.e., frequent buyer programs) have become common in the transportation and hospitality industries.

- General Motors has launched a cobranded credit card that allocates 5 percent of spending toward the purchase or lease of a new car.

- American Express has offered two airline tickets for heavy card use during a 6-month period.

- MCI's "Friends and Family" program has offered incentives to enroll friends and relatives with the company.

Generally, the goal of these programs is to establish a higher level of customer retention in profitable segments by providing increased satisfaction and value to certain customers. For example, many supermarket preferredshopper programs are targeted toward heavy users. The managerial justification for these programs is that increased customer satisfaction and loyalty have a positive influence on long-term financial performance (Anderson, Fornell, and Lehmann 1994; Reichheld and Sasser 1990).

Managers typically believe that it is desirable and expected for a properly executed loyalty rewards program to increase usage of the company's product or service offerings (O'Brien and Jones 1995). To determine the long-term efficacy of a loyalty rewards program, a company must quantify the program's influence on future purchase behavior (e.g., usage levels). Furthermore, it must verify that the positive financial outcomes of the rewards program exceed the investments made in the program. Unfortunately, there is virtually no prior research about the 
effect of loyalty programs on customer purchases of services or on company financial outcomes. Much of the research concerning loyalty has focused on packagedgoods markets (Bowman and Lele-Pingle 1997; Uncles and Laurent 1997) — despite the prevalence of loyalty programs in goods and services industries worldwide.

Do loyalty programs increase customers' satisfaction with the product/service offering and their satisfaction with the company? Do they increase the duration of customer-provider relationships and usage levels of products/services? These questions are critical to service organizations that must decide whether loyalty programs generate revenues that exceed their implementation costs, as well as decide whether loyalty programs are more profitable than other retention strategies such as service guarantees. Naturally, companies that offer loyalty reward programs believe that their programs have a long-run positive effect on customer evaluations and behavior. However, if loyalty rewards programs increase relationship durations and usage levels, then customers will be increasingly exposed to the complete spectrum of service experiences-including experiences that may cause customers to switch to another service provider (Keaveney 1995). Prior research has established the positive effect of customer satisfaction on loyalty and usage behavior (Bolton 1998; Bolton and Lemon 1999; Jones and Sasser 1995). Consequently, it seems likely that loyalty rewards programs will have a positive long-run effect on customer purchase behavior only when service experiences are generally satisfactory. In other words, the impact of loyalty rewards programs is likely to be moderated by customers' usage levels and their assessments of their service experiences. Unfortunately, there is no rigorous empirical research concerning the mechanism by which loyalty programs operate.

These observations suggest the following research question: Under what conditions will a loyalty rewards program have a positive effect on customer evaluations, behavior, and repatronage intentions? This article will address this question by developing and estimating a model of the influence of a loyalty rewards program on customers' decisions to repurchase a service and their decisions about how much to use the service. The model will focus on the multiple direct and indirect effects of loyalty programs on these two dependent variables. In particular, the model will describe how the effect of participation in a loyalty rewards program is moderated by differences-across customers and over time-in customers' service experiences and assessments of these experiences. Using the model, it will be possible to estimate the effectiveness of a loyalty program model in aiding customer retention and in providing value.

\section{PERSPECTIVE ON LOYALTY}

There are many reasons why customers maintain relationships with service providers (Bendapudi and Berry 1997; Dick and Basu 1994). Previous research has not specifically attempted to model the influence of a loyalty rewards program on customer evaluations, repatronage intentions, and purchase behavior in service industries (Rust and Metters 1996). Hence, this section reviews prior research concerning the antecedents of customer repatronage behavior for services to provide a foundation for our modeling effort.

\section{Repurchase Behavior}

There are few longitudinal studies of customer repatronage behavior over time. Crosby and Stephens (1987) found that whether customers had replaced their insurance policies or allowed them to lapse depended on their prior overall satisfaction with their whole life coverage. Bolton (1998) showed that prior overall satisfaction with a cellular service company is positively related to the duration of the customer-company relationship, and that this effect is larger when the customer has more extensive experience with the service company. Keaveney's (1995) criticalincident study of customer switching behavior in service industries found that customers switch service providers for many reasons, including pricing, inconvenience, core service failures, failed service encounters, response to failed service encounters, competition, and ethical problems. Recently, Bolton and Lemon (1999) showed that customers' usage of two continuously provided services depended on their prior satisfaction levels, their assessments of payment levels, and prices. Finally, there are some models of aggregate customer retention (e.g., Zahorik and Rust 1992), and some cross-sectional studies that show repatronage behavior depends on prior satisfaction (e.g., Gilly and Gelb 1982; Solnick and Hemenway 1992).

\section{Repurchase Intentions}

Since purchase intentions are easier to measure than behavior, there are numerous studies of repatronage intentions. However, these studies must be interpreted with caution because the predictive validity of intentions measures varies depending on the product, the measurement scale, the time frame, and the nature of the respondents (e.g., Morwitz 1997; Morwitz and Schmittlein 1992). For example, Riley, Ehrenberg, Castleberry, Barwise, and Barnard (1997) find that repeat purchase intentions are not firmly held. Several longitudinal studies show that customers' prior repatronage intentions directly affect their sub- 
sequent repatronage intentions (e.g., LaBarbera and Mazursky 1983). Repatronage intentions have also been shown to depend on customers' prior attitudes and satisfaction levels (e.g., Bearden and Teel 1983; Oliver 1980). Two recent articles have proposed process models of how a customer's repatronage intentions depend on his or her attitude about perceived service quality over time. In a laboratory study concerning hotel visits by executives, Boulding, Staelin, Kalra, and Zeithaml (1993) find that customers' attitudes are subject to a Bayesian-like updating during successive service experiences. Rust, Inman, and Zahorik (1995) develop and estimate a Bayesian model in which favorable disconfirmation increases preference for the chosen brand and unfavorable disconfirmation decreases preference.

\section{Summary}

The above-mentioned studies are very diverse. Nevertheless, these findings are generally consistent with the notion that customers make repatronage decisions on the basis of their predictions (i.e., expectations) concerning the value of a future product/service, where their predictions are extrapolated from prior experiences (e.g., satisfaction levels) about the product/s ervice.

\section{A MODEL OF CUSTOMER REPATRONAGE BEHAVIOR}

This section develops a process model of how customers' service experiences-including their experiences with the competition and loyalty programs-influence their repatronage behavior. We develop a model that describes how customers integrate their experiences about their service experiences, including their perceptions of competitors to make repatronage decisions. We also discuss how the decision processes of members of loyalty programs may differ from nonmembers. An overview of our conceptual framework is depicted in Figure 1. The remainder of this section identifies the antecedents of repatronage through a series of hypotheses and then summarizes the hypotheses in a mathematical model.

\section{Prior Repatronage Intentions}

We believe that customers make repatronage decisions $\left(\right.$ Decision $_{i t}$ ) by updating their assessments of repatronage intentions through a sequential anchoring and adjustment process in which the individual's prior repatronage intentions $\left(\right.$ Intent $_{i t}$ ) acts as an anchor that is adjusted by his or her assessments of new service experiences. The influence of prior repatronage intentions is likely to be very strong because research has shown that customers maintain the status quo to satisfy coping goals, thereby minimizing explicit confrontation of negative potential decision consequences (Luce 1998).

Hypothesis 1a: Customers' repatronage intentions have a positive effect on their subsequent repatronage decisions.

Effect of loyalty program membership. We believe that customers who are members of loyalty programs are more likely to make favorable repatronage decisions. Beyond this main effect, we also believe that members of loyalty programs will tend to have stronger ties to the service organization than nonmembers. (For example, the loyalty program may award frequent shopper rewards to encourage customer loyalty.) Hence, loyalty program members may be particularly likely to use coping mechanisms, so that they weigh prior repatronage intentions more heavily than nonmembers.

Hypothesis $1 b$ : Members of loyalty programs weigh repatronage intentions more heavily than nonmembers in making repatronage decisions.

\section{The Role of Regret}

Inman, Dyer, and Jia (1997) have shown that customers' postchoice evaluations reflect both satisfaction (cf. Oliver 1980) and regret (cf. Bell 1982; Loomes and Sugden 1982), where regret entails comparisons of attributes across competing alternatives. ${ }^{1}$ We extend this notion by predicting that service repatronage decisions depend on both satisfaction and postchoice regret. Specifically, we predict that customers' repatronage behavior will depend on a postconsumption assessment of their service relative to their expectations (satisfaction) and relative to the best competing service alternative (regret). ${ }^{2}$ We hypothesize that customers encode their satisfaction with their current service experience $\left(\mathrm{OwnSat}_{i t}\right)$ by making a comparison with their satisfaction with the service provided by a competing company $\left(\mathrm{CompSat}_{i t}\right)$ in making repatronage decisions.

Hypothesis 2a: When customers' assessments of current experiences are less satisfactory than competitors' service levels (i.e., OwnSatit < CompSatit), the perceived discrepancy will have a negative effect on their repatronage decisions, whereas when customers' assessments of experiences are more satisfactory than competitors' service levels (i.e., OwnSatit $>$ CompSatit), the perceived discrepancy will have a positive effect on their repatronage decisions. 
FIGURE 1

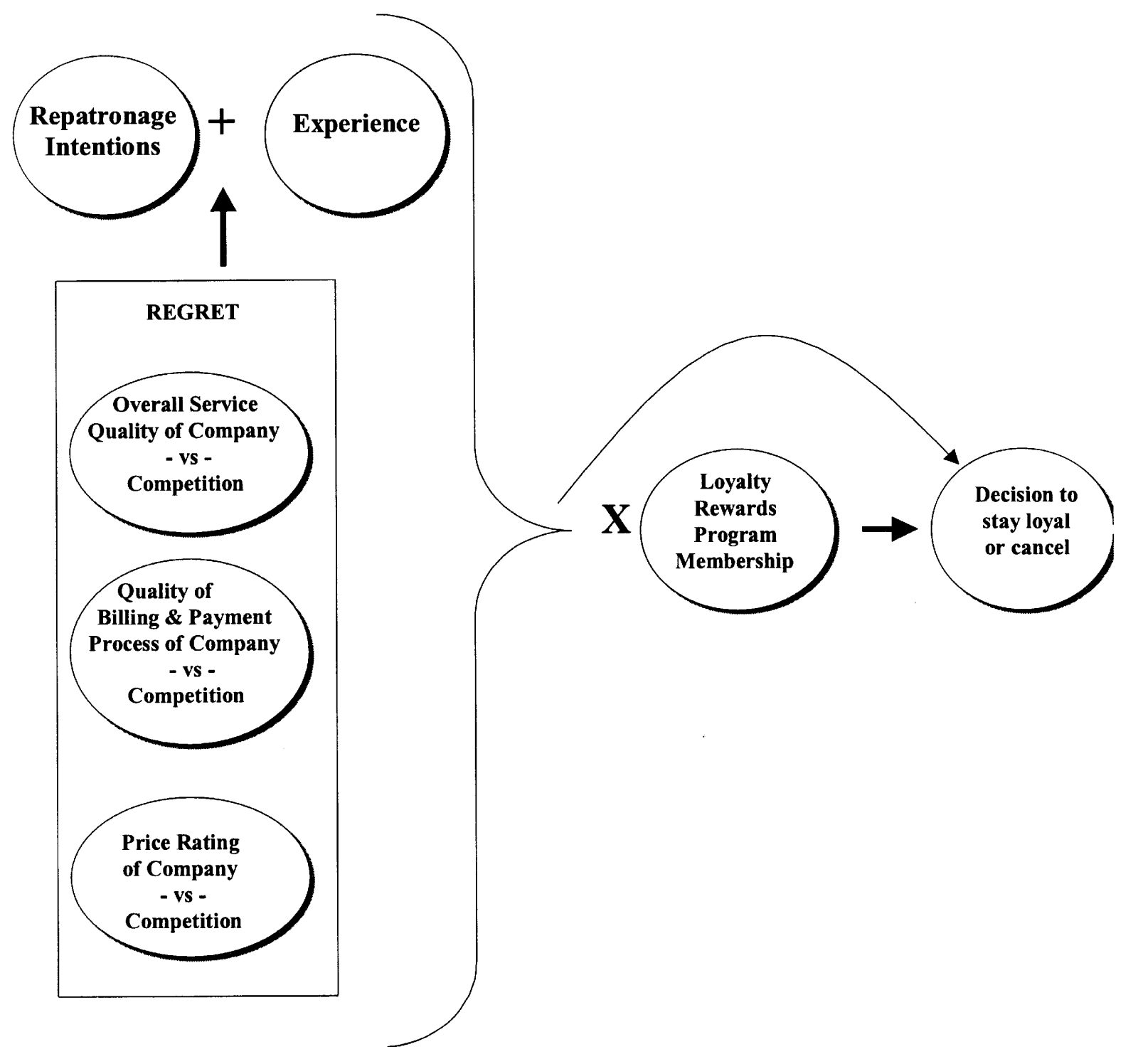

Since satisfaction is a postconsumption evaluation, this hypothesis is only relevant for situations in which the customer has experience with a competing alternative. However, there is a wide variety of products/servicesranging from cereals to airlines-for which customers have consumption experience with two or more competing alternatives.

Effect of loyalty program membership. The role of regret highlights how choice depends on the decision context (e.g., Simonson and Tversky 1992). Specifically, performance information about foregone alternatives can have a significant impact on postchoice valuation (e.g., Inman et al. 1997). In a competitive marketplace, both members and nonmembers of loyalty programs will have some experience with competing service providers. For example, most customers will have experiences with multiple long-distance companies, multiple financial institutions, multiple airlines, and so forth. However, members of loyalty programs are likely to be less knowledgeable-and less certain - about the performance of competing service alternatives than nonmembers because the bulk of their experience is with their current service provider. We predict 
that they will weigh their comparisons of satisfaction with the current service provider versus their competing service provider less heavily for the same reason.

Hypothesis $2 b$ : Members of loyalty programs will weigh comparisons with competitors less heavily than nonmembers in making repatronage decisions (after controlling for the effects of experience).

Asymmetric effects of regret. Prior research has shown that there are potential asymmetries in both the effects of expectancy disconfirmation and regret (e.g., Inman et al. 1997). Negative effects are usually more important in explaining customer evaluations. For example, Schul and Schiff (1993) find that negative experiences are likely to be processed more elaborately. (These findings are similar to the predictions of prospect theory, in which customers typically weigh losses more heavily than gains [e.g., Thaler 1985].) Hence, we predict that the negative effects of regret will be more important than positive effects in explaining repatronage decisions.

Hypothesis 3: The magnitude of the effect of customers' comparison of their satisfaction with their current provider versus their competing provider on their repatronage decisions will be larger when the discrepancy is negative, rather than positive.

We expect to find asymmetric effects for both members and nonmembers of loyalty programs.

\section{The Effect of Decreasing Comparability of Alternatives}

As the comparability of alternatives decreases, customers shift to an across-attribute strategy and make decreasing use of within-attribute processing (Johnson 1984). This shift seems very likely for repatronage decisions because comparable attributes receive more weight in comparison-based tasks (such as choice), whereas noncomparable attributes receive more weight when options are evaluated separately (Johnson and Auh 1999; Nowlis and Simonson 1997). Furthermore, "framing" the decision - that is, making certain decision criteria is more salient or available - can influence outcomes for both expert and novice customers when alternatives are noncomparable (Bettman and Sujan 1987). These findings suggest that noncomparable attributes will receive more weight as the comparability of alternatives decreases in repatronage decisions. This argument can explain why service failures have been shown to act as "triggers" that accelerate the customer's decision to discontinue a service relationship (Bolton 1998; Keaveney 1995). The presence of service failures decreases the comparability of the alternatives, and customers assign more weight to the presence/absence of service failures in their repatronage decisions. In other words, customers with larger numbers of noncomparable service experiences will incorporate these experiences into their repatronage decisions.

Hypothesis 4: Customers with noncomparable service experiences (e.g., exposure to unique companyspecific service experiences) will incorporate these experiences into their repatronage decisions.

\section{Summarizing the Repatronage Behavior Model}

The model describes two aspects of the repatronage decision $\left(\right.$ Decision $\left._{i t}\right)$ : the decision of whether or not to repurchase (i.e., stay/cancel credit card membership) and the decision of how much to use the service (i.e., usage level or number of transactions during the subsequent year). The model has two equations, each with the same basic specification. This specification captures the hypotheses algebraically as follows. Following Hogarth and Einhorn's (1992) belief updating model for "estimation tasks," we believe that customers' repatronage intentions are adjusted by an averaging process, in which a service experience is encoded as a deviation relative to a reference value or comparison standard. An attractive feature of this specification is that the reference value is the satisfaction provided by competitors - thereby blending the customer dis/satisfaction and choice modeling traditions. That is,

$$
\begin{aligned}
\text { Decision }_{i t} & =a_{A} \text { Intent }_{i t-1}+e_{A} \text { Loyal }_{i}+a_{L} \text { Loyal }_{i} \\
& \times \text { Intent }_{i t-1}+b_{A} \text { PosComp }_{i t-1}+c_{A} \text { NegComp }_{i t-1} \text { (1) } \\
& +b_{L} \text { Loyal }_{i} \times \text { PosComp }_{i t-1}+c_{L} \text { Loyal }_{i} \\
& \times \text { NegComp }_{i t-1}+d_{A} \text { NonComp }_{i t-1},
\end{aligned}
$$

where

$$
\begin{aligned}
& \text { Intent }_{i t-1}=\mathrm{a} \text { variable representing repatronage } \\
& \text { intentions; }
\end{aligned}
$$

If $\left(\right.$ OwnSat $_{i t-1}-$ CompSat $\left._{i t-1}\right)<0$, then:

NegComp it $-1=\left(\right.$ CompSat $_{i t-1}-$ OwnSat $\left._{i t-1}\right)$; and $\operatorname{PosComp}_{i t-1}=0$;

NonComp $_{i t-1}=$ a vector of variables describing noncomparable experiences, such as unique company-specific service experiences. 
Equation (1) distinguishes between the effects of perceived service experiences on all customers (denoted by the subscript $A$ ) and the effects on members of the loyalty program (denoted by the subscript $L$ ). It includes separate terms for positive and negative effects of comparisons with competitors to allow for asymmetrical effects on repatronage behavior, as well as including a separate vector to capture the effects of noncomparable experiences. Hypothesis 1a predicts that $a_{A}>0$. Hypothesis $1 \mathrm{~b}$ predicts that $a_{L}>0$. Hypothesis 2 a predicts that $b_{A}>0$ and $c_{A}<0$, and Hypothesis 3 predicts $\left|c_{A}\right|>\left|b_{A}\right|$ and $\left|c_{A}+c_{L}\right|>\left|b_{A}+b_{L}\right|$. Hypothesis $2 \mathrm{~b}$ predicts that $b_{L}<0, c_{L}>0$, and Hypothesis 4 predicts that $d_{A}>0$.

\section{THE DATABASE}

The model is estimated with cross-sectional, timeseries data from a worldwide financial services company that offers a loyalty reward program. This study focuses on credit card customers from three European countries, although these customers may also purchase other services from the company. The loyalty program is open to any card member, irrespective of usage. There is a fee to become a loyalty member, which varies depending on the country. (For example, in the United States it is about \$40). The loyalty program is a rewards-for-usage program. Loyalty rewards program members accumulate points with each dollar transacted that are redeemable for a wide variety of goods and services such as air certificates, car rental, vacation options, and retail gifts. At the time of the study, there were a few comparable rewards programs offered by competitors in these countries. The data describe a probability sample of 405 customers from the three European countries. $^{3}$

\section{Panel Design}

The database includes customer survey and usage behavior data for the period November 1995 through November 1997. The data were assembled using a panel design, in which survey measures and multiple waves of service usage records were obtained from the same customers-making causal inferences possible. We consider two distinct time periods. The initial time interval $(t=0)$ corresponds to a 12-month base time period (December 1995 to November 1996) in which service usage behavior is monitored. This initial time interval includes the administration of a survey in March 1996 - at which time all respondents were customers of the company. The subsequent time interval $(t=1)$ corresponds to a second 12month period (December 1996 to November 1997) in which service usage behavior is monitored.

Actual, rather than self-reported, measures of service usage levels were obtained-including number of trans- actions per year, dollars spent per year, and the duration of customer-company relationship. This feature is very important because light users typically overreport usage, whereas heavy users underreport usage, and because actual usage, rather than self-reported usage, is statistically related to satisfaction measures (Collopy 1996). The survey data include measures of customer perceptions of the company's and competitive service levels, corporate reputation, and self-reports of recent service experiences-as well as customers' intentions to recommend the company, renew credit card membership, and increase their share of business.

The database includes information about whether the customer canceled service during the time period of March 1996 to November 1997, as well as the cancellation date. Seventeen percent of the sample canceled their credit card during the study period. Equally important, the database also includes information about whether or not the customer is a loyalty rewards program member. Sixty-five percent of survey respondents were members of a rewards program offered by the financial-services provider. On average, respondents had held their credit card for about 9 years. However, the loyalty programs are quite a recent introduction in the three countries, all of them being introduced 2 to 3 years before the time of the study.

\section{Operationalization of Model Constructs}

Table 1 provides a list of the constructs used in the study along with a description of how they are measured. Recall that we estimate models for two aspects of the repatronage decision: the decision of whether or not to repurchase (i.e., stay/cancel credit card membership) and the decision of how much to use the service (i.e., usage level or number of transactions during the subsequent year). The decision of whether or not to repurchase $\left(\right.$ StayDecision $\left._{i t=1}\right)$ is measured by an indicator variable that indicates whether or not the subscriber canceled after March 1996 as tracked by the company (where 1 denotes canceled, 0 otherwise), and the decision of how much to use the service $\left(\right.$ UsageDecision $_{i t}=$ 1 ) is measured by the number of transactions at $t=1$ as tracked by the company.

In the StayDecision $_{i t=1}$ equation, repatronage intentions are calculated for each customer by averaging the values on three measures of repatronage intentions: likelihood to recommend company, likelihood to renew the company's product, and likelihood to increase the share with the company. Each of these measures ranges from 1 to 5 , resulting in a range of 1 to 5 for the overall index. In the UsageDecision $_{i t=1}$ equation, we operationalize repatronage usage intentions by a measure of the duration of the customer's membership in the loyalty program. (The rationale is that longtime users are likely to anticipate 
TABLE 1

Model Constructs

\begin{tabular}{|c|c|c|}
\hline Construct & Measure & Reliability \\
\hline \multicolumn{3}{|l|}{ Dependent variables } \\
\hline StayDecision $_{i t}$ & $\begin{array}{l}\text { Indicator variable that takes on the value } 1 \text { if the subscriber canceled service and } 0 \text { if the } \\
\text { subscriber retained service, during } t=1 \text {. }\end{array}$ & \\
\hline UsageDecision $_{i t}$ & Number of transactions during $t=1$. & \\
\hline \multicolumn{3}{|l|}{ Predictor variables } \\
\hline \multirow[t]{2}{*}{ Intent $_{i t-1}$} & $\begin{array}{l}\text { StayDecision }_{i t} \text { : Measure of repatronage intention of the customer toward the company, } \\
\text { which is the average of three items: his or her likelihood to recommend, to renew, or } \\
\text { to increase share with company. }\end{array}$ & Cronbach's alpha $=.69$ \\
\hline & UsageDecision $_{i t}$ : Duration of the customer's relationship with the company. & \\
\hline \multirow[t]{5}{*}{ OwnSat $_{i t-1}$} & $\begin{array}{l}\text { Measured on four dimensions: billing aspects, product benefits, overall quality, overall } \\
\text { price. }\end{array}$ & \\
\hline & $\begin{array}{l}\text { Average of vector of ratings variables describing the company's current service levels on } \\
\text { billing aspects: reasonable time to make payments, ease of reading and understanding } \\
\text { statements. }\end{array}$ & 1. Cronbach's alpha $=.54$ \\
\hline & $\begin{array}{l}\text { Average of vector of ratings variables describing the company's product benefits: } \\
\text { dependable, for successful people, good for travelers, best for business people, } \\
\text { prestigious product. }\end{array}$ & 2. Cronbach's alpha $=.76$ \\
\hline & Overall quality & \\
\hline & Overall price & \\
\hline CompSat $_{i t-1}$ & $\begin{array}{l}\text { Calculated as above for competitors: billing aspects, product benefits, overall quality, } \\
\text { overall price. }\end{array}$ & $\begin{array}{l}\text { 1. Cronbach's alpha }=.66 \\
\text { 2. Cronbach's alpha }=.75\end{array}$ \\
\hline NonComp $_{\text {it }-1}$ & $\begin{array}{l}\text { Vector of indicator variables where } 1 \text { indicates the presence of an event and } 0 \text { its absence: } \\
\text { replacement of card, called customer service, used card to obtain cash, experienced } \\
\text { any problems. }\end{array}$ & \\
\hline Intent $^{*}$ Loyalty $_{I}$ & $\begin{array}{l}\text { Intentions measure, multiplied by an indicator variable that takes on the value } 1 \text { if the } \\
\text { subscriber was a member of the loyalty program, } 0 \text { otherwise. }\end{array}$ & \\
\hline Experience $_{i t-1}$ & Number of transactions during $t=0$ & \\
\hline
\end{tabular}

using their card more heavily.) Loyalty ${ }_{i}$ is an indicator variable indicating whether Loyalty $_{i=1}$ ) or not Loyalty $\left._{i=0}\right)$ the customer is a member of the loyalty program as recorded by the company. These two variables are multiplied to create the interaction term shown in equation (1).

Each regret construct $\left(\operatorname{PosComp}_{i t=0}, \mathrm{NegComp}_{i t=0}\right)$ is calculated as the difference between the customer's satisfaction with the company versus a competitor. Regret gain variables $\left(\right.$ PosComp $\left._{i t=0}\right)$ are calculated by subtracting the rating for the competitor from the rating for the company and resetting negative scores to zero. Regret loss variables are defined by subtracting the rating for the company from the rating for the competitor and resetting negative scores to zero. These calculations are made for four different dimensions of the service experience: the billing process, product benefits, overall service, and price. Satisfaction with billing and product benefits are each measured by an index created from self-report measures on a 5-point Likert scale, obtained by surveying customers. The Cronbach alpha values in Table 1 indicate that the indices used in the model have reasonably good reliability. Satisfaction with overall service and price are each measured by a single item measured on a 5-point Likert scale. Since values on the ratings variables for both company and competitor range from 1 to 5 , there is a potential range of 0 to 4 on the regret gain and loss variables. The loss and gain variables were calculated at the index level for billing process and product benefits, and at the variable level for overall quality and price. The vector of variables describing noncomparable or company-specific service experiences is represented by indicator variables that denote the presence/absence of the service experience.

Both equations incorporate a covariate $\left(\right.$ Experience $\left._{i t=0}\right)$, measured as the number of discrete transactions (not billings) made by the customer in the base time period as measured by the company. The correlations among all of the independent variables were quite low ranging from -.26 to .19 , ensuring that there are no significant confounding effects.

\section{Descriptive Statistics}

Table 2 shows summary descriptive statistics for variables in the model. In estimating the model, nonoverlapping item, nonresponse on variables in the model results in an effective sample size of 257. Statistics in Table 2 are therefore calculated across these 257 observations. Table 2 shows that the average value for the repatronageintentions index is 3.8 , indicating a high average likelihood of overall repatronage intentions. The relative average sizes of the billing dimension gain and loss variables (.656 and .134, respectively) indicate that on average, 
TABLE 2 Summary Descriptive Statistics

\begin{tabular}{lc}
\hline Variable & M (SD) \\
\hline Gain, billing aspects index (company_competitor) & $0.656(0.793)$ \\
Loss, billing aspects index (competitor_company) & $0.134(0.368)$ \\
Gain, quality rating (company_competitor) & $0.436(0.699)$ \\
Loss, quality rating (competitor-company) & $0.148(0.501)$ \\
Gain, price rating (company_competitor) & $0.144(0.432)$ \\
Loss, price rating (competitor_company) & $0.837(0.958)$ \\
Gain, product rating (company_competitor) & $0.848(0.799)$ \\
Loss, product rating (competitor-company) & $0.067(0.233)$ \\
Index of company repatronage intentions & $3.767(0.838)$ \\
Number of transactions past 12 months & $3.327(5.322)$ \\
Cancellation binary indicator & $0.187(0.390)$ \\
Loyalty program member binary indicator & $0.693(0.462)$
\end{tabular}

more gain than loss is experienced by these customers in terms of aspects of account billing and payment. Likewise, in terms of the customers' product rating and the rating for overall quality, average levels of gain exceed average loss, although by a greater margin for product rating (.848 and .067 , respectively) and by a lesser amount for overall quality (.436 and .148, respectively). Customers are rating the company higher than the competitor on aspects of billing and payment, on aspects of the product, and on overall quality. However, this pattern is reversed for the customers' rating for the price that they pay on this product: on average, more loss than gain is indicated by these customers in this dimension (.837 and .144, respectively).

Table 2 also indicates that the average number of transactions per account last year was 3.3, with a relatively large standard deviation of 5.3. This is partly due to a high incidence of product nonusage, as indicated by zero transactions last year, which brings the average value for the number of transactions last year down. Table 3 presents an abridged frequency distribution of the number of transactions last year to help clarify this statistic. Forty-three percent of the sample had zero transactions last year. Table 2 also shows that 19 percent of the sample has canceled their accounts, while 69 percent of the sample are loyalty program members. The percentage of customers who cancel their account differs by whether the customers are members of the loyalty program. (Table 4 presents a comparison of many variables across the two segments to provide profile details.) It indicates that customers who are members of the loyalty program are less likely to cancel their accounts than are nonmembers. Whereas slightly more than 25 percent of the nonmembers have canceled their accounts, only 15.7 percent of the loyalty program members have canceled. A chi-square test of independence between these two variables results in a chi-square value of 3.31 , with 1 degree of freedom, indicating a relationship between these variables that is statistically significant at the 0.07 percent level.
TABLE 3

Frequency Distribution, Number of Transactions Last Year

\begin{tabular}{lcc}
\hline Value & Frequency & Percentage \\
\hline 0 transactions & 111 & 43.2 \\
1-5 transactions & 93 & 36.2 \\
6-10 transactions & 30 & 11.7 \\
11-15 transactions & 11 & 4.2 \\
16-20 transactions & 6 & 2.4 \\
$>$ 20 transactions & 6 & 2.4 \\
Total & 257 & 100.1 \\
\hline
\end{tabular}

NOTE: Percentages do not total exactly to 100 due to rounding.

\section{TABLE 4} Summary Descriptive Statistics by Loyalty Program Membership

\begin{tabular}{|c|c|c|}
\hline & $\begin{array}{l}\text { Not Loyalty } \\
\text { Member }\end{array}$ & $\begin{array}{l}\text { Loyalty } \\
\text { Member }\end{array}$ \\
\hline Variable & $\mathrm{M}(\mathrm{SD})$ & $\mathrm{M}(\mathrm{SD})$ \\
\hline Gain, billing aspects index & $0.664(0.741)$ & $0.654(0.817)$ \\
\hline Loss, billing aspects index & $0.108(0.296)$ & $0.146(0.396)$ \\
\hline Gain, quality rating & $0.304(0.607)$ & $0.494(0.731)$ \\
\hline Loss, quality rating & $0.266(0.711)$ & $0.096(0.363)$ \\
\hline Gain, price rating & $0.278(0.553)$ & $0.084(0.350)$ \\
\hline Loss, price rating & $0.722(1.012)$ & $0.888(0.932)$ \\
\hline Gain, product rating & $0.793(0.744)$ & $0.873(0.823)$ \\
\hline Loss, product rating & $0.074(0.236)$ & $0.064(0.232)$ \\
\hline $\begin{array}{l}\text { Index of company } \\
\text { repatronage intentions }\end{array}$ & $3.717(0.961)$ & $3.789(0.779)$ \\
\hline $\begin{array}{l}\text { Usage: number of } \\
\text { transactions }\end{array}$ & & \\
\hline last 12 months & $1.038(1.958)$ & $4.343(5.992)$ \\
\hline $\begin{array}{l}\text { Usage: total } \$ \text { spending } \\
\text { last } 12 \text { months }\end{array}$ & $1,882.87(4,439.32)$ & $5,792.59(7,947.59)$ \\
\hline $\begin{array}{l}\text { Cancellation binary } \\
\text { indicator }\end{array}$ & $0.253(0.438)$ & $0.157(0.365)$ \\
\hline
\end{tabular}

\section{MODEL ESTIMATION AND RESULTS}

The equation describing the decision of whether to repurchase $\left(\right.$ StayDecision $_{i t=1}$, cancellation $=1$, and retention $=0$ ) is estimated as a logistic regression, and the equation describing the decision of how much to use the service (UsageDecision $_{i t=1} \geq 0$ ) is estimated as a tobit model (following Tobin 1958; see Judge, Hill, Griffiths, Lutkepohl, and Lee 1988). In both equations, the interaction term Loyal $_{i}$ Intent $_{i t-1}$ was not statistically significant. Hence, this term was dropped from both equations. Furthermore, the vector of variables describing noncomparable or company-specific service experiences was not significant in the StayDecision ${ }_{i t=1}$ equation, so these variables were 
TABLE 5 Logistic Regression Model of Account Retention

\begin{tabular}{lcc}
\hline Variable & $\begin{array}{c}\text { Parameter } \\
\text { Estimate (SE) }\end{array}$ & $\begin{array}{c}\text { Odds } \\
\text { Ratio }\end{array}$ \\
\hline Intercept & $-0.072(1.078)$ & - \\
Number of transactions & $0.852(0.213)$ & $2.345^{* * *}$ \\
Repatronage intentions & $0.497(0.241)$ & $1.644^{* *}$ \\
Loyalty program member & $-1.305(0.810)$ & 0.271 \\
Gain, billing aspects & $-0.696(0.487)$ & 0.499 \\
Loss, billing aspects & $-2.207(1.156)$ & $0.110^{*}$ \\
Gain, quality rating & $-0.309(0.567)$ & 0.734 \\
Loss, quality rating & $-1.338(0.647)$ & $0.262^{* *}$ \\
Gain, price rating & $1.976(1.159)$ & $7.210^{*}$ \\
Loss, price rating & $-0.399(0.344)$ & 0.671 \\
Loyalty*Gain, billing & $0.698(0.601)$ & 2.010 \\
Loyalty*Loss, billing & $3.020(1.377)$ & $20.486^{* *}$ \\
Loyalty*Gain, quality & $0.106(0.662)$ & 1.112 \\
Loyalty*Loss, quality & $1.580(0.889)$ & $4.855^{*}$ \\
Loyalty*Gain, price & $-2.416(1.272)$ & $0.089^{*}$ \\
Loyalty*Loss, price & $0.576(0.448)$ & 1.782 \\
& & \\
-2 log likelihood $\chi^{2}$ & 74.85 with 15 & \\
& $d f(p \leq .0001)$ & \\
$N$ & 256 & \\
Model fit & $204.648($ AIC) & 261.433 (Schwartz) \\
Model fit—competing & & \\
model & $209.956($ AIC) & 266.742 (Schwartz) \\
\hline
\end{tabular}

$* p \leq .10 . * * p \leq .05 . * * * p \leq .01$.

dropped as well. Tables 5 and 6 show the estimation results for both equations after dropping these nonsignificant terms. Table 5 presents the results of the logistic regression model of customer retention. Table 6 presents the results of the maximum-likelihood estimation of the tobit model of usage behavior.

Likelihood ratio tests indicate that both models fit the data very well. The logit model correctly predicts 85 percent of customers decisions-well above chance levels. Equally important, an alternate specification for estimating the impact of customers' evaluations of clients' and competitors' product quality, price, and billing services on customer retention is to include these measures directly in the model instead of including gains and loss variables on these dimensions. In comparing this competing specification with our current model, our model provides as good or better fits on both the Akaiake Information Criterion and Schwartz's Bayesian Criterion, lending clear support to our specification (Tables 5 and 6). Comparisons with other more parsimonious competing models (not reported) also favor our specification.

In the following paragraphs, we will first focus on the results of the model of retention and then discuss the results of the model of usage.
TABLE 6 Tobit Regression Model of Account Usage

\begin{tabular}{|c|c|c|}
\hline Variable & Parameter Estimate & SE \\
\hline Intercept & $-11.879 * * *$ & 2.776 \\
\hline $\begin{array}{l}\text { Number of transactions, } \\
\text { prior year }\end{array}$ & $0.000279 * * *$ & 0.000053 \\
\hline Membership duration & -0.00503 & 0.00665 \\
\hline Loyalty program member & $8.0835 * * *$ & 2.631 \\
\hline Gain, product rating & $2.790^{*}$ & 1.455 \\
\hline Loss, product rating & -6.457 & 9.0172 \\
\hline Gain, quality rating & -3.0441 & 1.976 \\
\hline Loss, quality rating & 2.464 & 1.637 \\
\hline Gain, price rating & $4.0538 * *$ & 1.965 \\
\hline Loss, price rating & $2.161 * *$ & 1.0295 \\
\hline Loyalty*Gain, product & -1.606 & 1.624 \\
\hline Loyalty*Loss, product & 8.838 & 9.295 \\
\hline Loyalty*Gain, quality & 3.341 & 2.129 \\
\hline Loyalty*Loss, quality & -2.0777 & 2.232 \\
\hline Loyalty*Gain, price & $-6.916 * * *$ & 2.535 \\
\hline Loyalty*Loss, price & -1.897 & 1.179 \\
\hline Used product abroad & $3.799 * * *$ & 1.221 \\
\hline Called customer service & $2.346^{* *}$ & 0.954 \\
\hline (Normal) scale parameter & 6.406 & 0.395 \\
\hline$N$ & 256 & \\
\hline Model fit & $1,115.548$ (AIC) & $1,179.358$ (Schwartz) \\
\hline $\begin{array}{l}\text { Model fit- } \\
\text { competing model }\end{array}$ & $1,114.726$ (AIC) & $1,178.536$ (Schwartz) \\
\hline
\end{tabular}

$* p \leq .10 . * * p \leq .05 . * * * p \leq .01$.

\section{Logistic Regression Model of Account Retention}

Prior repatronage intentions and the moderating effect of loyalty program membership (Hypotheses $1 a$ and $1 b$ ). Intent $t_{i}$ is positively related to the probability of retention and supports our hypothesis. An increase of 1 point on the index of repatronage intentions yields a probability of retention 1.644 times higher, indicating that the influence of prior repatronage intention is quite strong (as hypothesized).

The main effect of being a member of the loyalty program is not statistically significant. In other words, being a member of the loyalty program per se does not directly affect the chances of account retention. As mentioned above, statistical tests indicate that members of loyalty programs do not weigh repatronage intentions more heavily than nonmembers in making repatronage decisionsrejecting Hypothesis 1b. However, we have hypothesized additional interaction variables involving loyalty programs that are significant in the model, so we will consider the effects of loyalty program membership further (below). 
Regret and the moderating effect of loyalty program membership (Hypotheses $2 a$ and $2 b$ ). Customers' evaluation of the company's billing aspects relative to competitors has a significant impact on the probability of repatronage. In general, losses on this dimension significantly lower the probability of repatronage, while gains have no appreciable impact on repatronage decision. However, this effect is moderated by customers' membership in loyalty programs. For loyalty program members, the net impact of losses on the probability of repatronage is not significant $(-2.207$ for the loss coefficient and 3.020 for the loyalty/loss coefficient, with the combined effect not statistically significant: see Table 7). This result indicates that loyalty program members overlook the losses suffered in this dimension and do not penalize the company for it.

Loss in terms of the rating of overall quality has a significant negative effect on repatronage, while gain does not have a significant effect on repatronage. Again, these effects are moderated by respondents' membership in loyalty programs. Table 7 shows that for loyalty program members, the net impact of a loss on the quality dimension on the probability of repatronage is insignificant, as is the impact of gain. This result again lends support to the notion that loyalty members discount the lower evaluations of the company vis-à-vis the competitors with regard to their repatronage decision.

On the dimension of overall price rating, the results are somewhat different. Gain in terms of the rating of price has significant positive impact on repatronage, while loss on the overall price rating has no significant impact on repatronage decision. These effects are moderated by the loyalty program membership. While the impact of loss on the price dimension on retention remains insignificant for the loyalty program customers, the impact of gain on the price dimension on repatronage decision is also insignificant (Table 7).

The above results generally support Hypotheses $2 \mathrm{a}$ and $2 \mathrm{~b}$ that we put forth in our model. While the impact of gain on the billing aspects and overall quality on repatronage was insignificant, the impact of a loss on these dimensions on repatronage was significantly negative as hypothesized. This result along with the result for the overall price rating generally supports Hypothesis $2 \mathrm{a}$. The moderating impact of loyalty program membership on these effects (making them less significant and less important for repatronage decisions) supports Hypothesis $2 \mathrm{~b}$.

Asymmetric effects of regret (Hypothesis 3 ). The results also support the notion that customers weigh the losses more than the gains in evaluating repatronage. Both in the case of billing aspects and overall quality the impact of losses was larger in magnitude as compared with the impact of gains, as expected. However, on the overall pricerating dimension, the magnitude of the impact of gain on repatronage is larger than the magnitude of the impact of
TABLE 7 $t$ Tests, Main and Interaction Combined Effects

\begin{tabular}{llc}
\hline Main Effect & \multicolumn{1}{c}{$\begin{array}{c}\text { Interaction } \\
\text { Effect }\end{array}$} & $\begin{array}{c}\mathrm{t} \text { Statistic } \\
\text { (significance) }\end{array}$ \\
\hline Retention model & & \\
Gain, billing aspects & Loyalty*Gain, billing aspects & $0.00162(n s)$ \\
Loss, billing aspects & Loyalty*Loss, billing aspects & $0.438(n s)$ \\
Gain, quality rating & Loyalty*Gain, quality rating & $-0.185(n s)$ \\
Loss, quality rating & Loyalty*Loss, quality rating & $0.206(n s)$ \\
Gain, price rating & Loyalty*Gain, price rating & $-0.249(n s)$ \\
Loss, price rating & Loyalty*Loss, price rating & $0.141(n s)$ \\
Usage model & & \\
Gain, product rating & Loyalty*Gain, product rating & $0.207(n s)$ \\
Loss, product rating & Loyalty*Loss, product rating & $0.0142(n s)$ \\
Gain, quality rating & Loyalty*Gain, quality rating & $0.0322(n s)$ \\
Loss, quality rating & Loyalty*Loss, quality rating & $0.0493(n s)$ \\
Gain, price rating & Loyalty*Gain, price rating & $-0.274(n s)$ \\
Loss, price rating & Loyalty*Loss, price rating & $0.0711(n s)$ \\
\hline
\end{tabular}

NOTE: $t$-statistics calculated as the sum of the main and interaction coefficients divided by the square root of the sum of the squared main and interaction standard errors plus twice the covariance of the main and interaction variables.

loss on repatronage. This needs some explanation. The fact that this magnitude difference on overall price dimension does not exist for loyalty program members is very relevant here (recall that the effects of loss and gain on repatronage are both insignificant for loyalty program members). This observation suggests that this effect applies mainly to those who are not loyalty program members, who could be using several other cards and switching among them. Extant research in reference price effects on choice has found that for customers who switch often in their purchase of customer package goods, the impact of gain on the price dimension on choice is larger in magnitude than the impact of loss on choice (Krishnamurthi, Mazumdar, and Raj 1992; Mazumdar and Papatla 1995). Our results may indicate that similar effects exist in the case of service usage and retention.

The effect of decreasing comparability of alternatives (Hypothesis 4). Statistical tests showed no effect of decreasing comparability of alternatives on account retention. Hence, Hypothesis 4 is not supported. This issue is discussed further below.

Effects of experience. The inclusion of the covariate representing experience is also noteworthy. As expected, experience with the product, as indicated by the number of transactions last year, is strongly associated with a higher likelihood of repatronage. Each additional transaction added yields a more than doubled chance of retention (the odds ratio is 2.345). This is in line with the results of Schmittlein, Morrison, and Colombo (1987) and Schmit- 
tlein and Peterson (1994), who find that customers with very few transactions are most likely to cancel. ${ }^{4}$

\section{Tobit Model of Account Usage}

Table 6 provides the results of the tobit regression model of usage where usage behavior is measured by the number of transactions. (Note that customers' number of transactions is positively affected by the number of transactions they had in the previous year.) Since many of the results are similar to the logit model of account retention, we focus on new findings.

The moderating effect of loyalty program membership (Hypotheses $1 a, 1 b, 2 a, 2 b, 3$ ). Hypotheses $1 \mathrm{a}$ and $1 \mathrm{~b}$ are not supported. The effect of membership duration (Intent . $_{i}$ is not statistically significant—probably because the effect of the prior year's number of transactions (Experience $_{i t=0}$ ) is highly statistically significant. (Under these circumstances, it is not surprising that the interaction of membership duration and loyalty program membership was not statistically significant.) However, the main effect of loyalty program membership is highly statistically significant. In other words, loyalty program members use their credit card more than nonmembers.

Customers' evaluation of the company relative to competitors (i.e., regret) also has a significant impact on credit card usage. In particular, the results concerning the impact of loyalty program membership on usage are very similar to the results of the model of retention. Being a loyalty program member has a strong positive impact on the number of transactions. For nonloyalty program members, gains on the product dimension have a positive impact on the number of transactions, while gains and losses on the quality dimension have no impact on the number of transactions. Both gains and losses on the price dimension have a positive impact on usage, with the magnitude of the impact of gains much larger than the impact of losses. While the positive impact of losses is counterintuitive, this anomaly could be attributed to measuring usage behavior by using just one dimension, number of transactions, and not supplementing it with total spending or average spending per transaction. ${ }^{5}$ The interaction effect of loyalty program membership on the gains and losses is identical to those found in the model of repatronage decision. As before, the loyalty program membership moderates the impact of gains and losses on the number of transactions (see Table 7). These results lend further support to Hypotheses 2 and 3.

The effect of decreasing comparability of alternatives (Hypothesis 4). Recall that, in testing alternative specifications of the logit model of account retention, we found no effect due to variables representing decreasing comparability of alternatives. In contrast, in the tobit model of account usage, the number of transactions is positively
TABLE 8 Gain and Loss $t$ Tests by Loyalty Program Membership

\begin{tabular}{|c|c|c|c|}
\hline Variable & $\begin{array}{l}\mathrm{M}(\mathrm{SD}) \\
\text { Loyalty } \\
\text { Members }\end{array}$ & $\begin{array}{c}\text { M (SD) } \\
\text { Nonmembers }\end{array}$ & $\begin{array}{c}\text { t Test, } \\
\text { Difference } \\
\text { of Means }\end{array}$ \\
\hline Gain, product rating & $0.873(0.823)$ & $0.793(0.744)$ & -0.773 \\
\hline Loss, product rating & $0.064(0.232)$ & $0.074(0.236)$ & 0.323 \\
\hline Gain, billing aspects & $0.654(0.817)$ & $0.666(0.741)$ & 0.0937 \\
\hline Loss, billing aspects & $0.146(0.396)$ & $0.108(0.296)$ & -0.863 \\
\hline Gain, quality rating & $0.494(0.731)$ & $0.304(0.607)$ & $-2.0282 * *$ \\
\hline Loss, quality rating & $0.0956(0.363)$ & $0.266(0.711)$ & $2.0158 * *$ \\
\hline Gain, price rating & $0.0843(0.350)$ & $0.278(0.553)$ & $2.875^{* * * *}$ \\
\hline Loss, price rating & $0.888(0.932)$ & $0.722(1.012)$ & -1.284 \\
\hline
\end{tabular}

$* p \leq .10 . * * p \leq .05 . * * * p \leq .01$.

related to customers using the credit card abroad and to customers calling customer service. This credit card company has a reputation for universal acceptability and renowned customer service. Customers who use the card abroad or interact with the company's customer service experience its unique features and thus are likely to view alternative credit cards as less comparable. Hence, the positive impact of these two variables supports Hypothesis 4.

\section{DISCUSSION}

The study findings suggest that customers make repatronage decisions for the credit card service on the basis of their prior repatronage intentions or behavior, updated by comparisons of their prior satisfaction levels with the company versus their satisfaction with a competitor. However, their comparisons are relatively complex-customers make comparisons on multiple underlying service dimensions and (usually) weigh losses more heavily than gains.

The main inference regarding the effect of loyalty program that emerges from our results is as follows. Members in loyalty programs are generally less sensitive to losses in the dimensions of overall quality rating and billing aspects when comparing the company with competitors and less sensitive to overall price advantages that competitors could have vis-à-vis the company. In other words, they overlook or discount negative evaluations of the company vis-à-vis the competition. This can be supported further by viewing the summary descriptive statistics of the gain and loss variables for those customers who are members of the loyalty program (Table 8 ).

As seen in Table 8 , members of the loyalty program generally have larger gains than losses on the billing aspects index and overall quality rating, and they generally have larger losses than gains on the overall price dimension when comparing the company with the competitors. Yet, they discount these evaluations in their repatronage decisions. One possible reason could be that they perceive 
that they are getting better quality and service for their price or, in other words, good value. Thus, one could hypothesize that being members of loyalty programs and perceptions of good value are highly correlated. However, inferring a cause-effect relationship could be more difficult. Could we claim that being part of a loyalty program leads a perception of good value among customers? Or is it the perception of good value that motivates customers to become members of the loyalty program? This is difficult to infer from the limited scope of our survey questionnaire. Nevertheless, the important implication is that perception of a value hypothesis and loyalty programs are complementary and are necessary to build a lasting relationship with customers.

Our data set describes three European markets in which loyalty programs were in their infancy and customers do not use their credit card frequently. It would be interesting to compare these results with a study of a market in which loyalty programs are more prevalent and customers are heavy users. (Our small sample size prevented any meaningful analysis of market segments based on transaction amounts and/or frequency). Nevertheless, our results do show the usefulness of analyzing transaction data in conjunction with survey information from customers in gauging the effectiveness of loyalty programs. Furthermore, it seems likely that similar process may operate-although there may be differences in the relative importance of the various drivers of repatronage intentions.

\section{MANAGERIAL IMPLICATIONS}

Do loyalty programs create loyalty to the brand - or loyalty to the loyalty program? This question summarizes the two directly opposing views regarding the effectiveness of loyalty rewards programs. One view is that loyalty rewards programs operate as a form of mass customization that strengthens customers' perceptions of the company's value proposition. In other words, this view argues that these programs encourage customer loyalty and usageeven when a negative service experience occurs. An alternative view is that loyalty rewards programs encourage customers to become more demanding concerning product/ service benefits and price. In other words, this view argues that these programs "create" a deal-prone segment.

In our study, the credit card company's loyalty program apparently strengthens customers' perceptions of the value proposition and causes them to discount their evaluations of the company vis-à-vis competitors in making their repatronage decisions. These observations are consistent with the traditional notion that loyalty rewards programs provide an opportunity to build longer, stronger, and deeper relationships with customers. Our statistical analyses show that the credit card company's loyalty program leads to increased revenues due to fewer cancellations and higher service usage levels. However, we can only speculate whether the higher revenues offset the company's costs of operating the program. These findings may generalize to other consumer products and services. However, their generalizability partially depends on the effectiveness with which the loyalty program is implemented. Hence, further research is required concerning the underlying mechanism by which loyalty rewards programs operate to influence customers' assessments and repatronage behavior. For example, it would be useful to understand what features of a loyalty rewards program are operating to create these changes in customers' assessments and behavior.

This research domain seems particularly fruitful because the implementation of a loyalty rewards program may encourage more profitable managerial practices. Specifically, it is theoretically more profitable to segment and target customers on the basis of their (changing) purchase behavior and service experiences rather than on the basis of their (stable) demographics or other classification variables. The increasingly important role that information technology plays in today's companies is an important enabler of such practices.

\section{ACKNOWLEDGMENTS}

The authors gratefully acknowledge the assistance of Walker Information in providing the data and the research assistance of Kevin Murley. We also thank John Deighton, Naveen Donthu, and Praveen Kopalle for their helpful reviews of the earlier draft.

\section{NOTES}

1. Prior research has shown that customers strive to make choices with the lowest probability of postpurchase regret; that is, their initial choices reflect anticipatory regret (e.g., Simonson 1992).

2 . We consider satisfaction to be a postconsumption fulfillment response that primarily depends on the difference between customers' expectations and perceptions of performance (Oliver 1980). We consider regret to be the "difference in value between the assets actually received and the highest level of assets produced by other alternatives" (Bell 1982).

3. The correlation between frequency of transactions and loyalty dummy was quite low (.28 for transactions in the first year and .30 for transactions in the second year), thus rejecting the notion that loyalty program members were also high-transaction customers. This ensures that there is no material confound in the data on this dimension.

4. Two studies suggest that, as a customer gains more confidence or experience in evaluating a service, he or she weighs prior evaluations more heavily than new information (cf. Bolton 1998; Boulding, Kalra, and Staelin 1997). These findings suggest that the magnitude of the effect of prior repeat purchase intentions may be larger for customers who have had longer or more intensive relationships with their current service provider. However, statistical tests rejected this notion.

5 . However, this concern is mitigated on further analysis of the usage of those nonloyal consumers who have experienced losses on the price di- 
mension. We found that two outlier observations with large losses and an unusually large number of transactions were skewing the general pattern of a negative impact.

\section{REFERENCES}

Adams, J. Stacy. 1965. "Inequity in Social Exchange.” In Advances in Experimental Social Psychology, Vol. 2. Ed. Leonard Berkowitz. New York: Academic Press, 267-299.

Anderson, Eugene W., Claes Fornell, and Donald R. Lehmann. 1994. "Customer Satisfaction, Market Share and Profitability: Findings From Sweden." Journal of Marketing 58 (July): 53-66.

Bearden, William O. and Jesse E. Teel. 1983. "Selected Determinants of Customer Satisfaction and Complaint Reports." Journal of Marketing Research 20 (February): 21-28.

Bell, David E. 1982. "Regret in Decision Making Under Uncertainty." Operations Research 30:961-981.

Bendapudi, Neeli and Leonard L. Berry. 1997. "Customers' Motivations for Maintaining Relationships With Service Providers." Journal of Retailing 73 (1): 15-37.

Bettman, James R. and Mita Sujan. 1987. "Effects of Framing on Evaluation of Comparable and Noncomparable Alternatives by Expert and Novice Customers." Journal of Customer Research 14 (September): 141-154.

Bolton, Ruth N. 1998. "A Dynamic Model of the Duration of the Customer's Relationship With a Continuous Service Provider: The Role of Satisfaction." Marketing Science 17 (1): 45-65.

— and Katherine N. Lemon. 1999. "A Dynamic Model of Customers' Usage of Services: Usage as an Antecedent and Consequence of Satisfaction." Journal of Marketing Research 36 (2): 171-186.

Boulding, William, Richard Staelin, Ajay Kalra, and Valarie Zeithaml. 1993. "A Dynamic Process Model of Service Quality: From Expectations to Behavioral Intentions." Journal of Marketing Research 30 (February): 7-27.

- Ajay Kalra, and Richard Staelin. 1997. "The Quality Double Whammy: The Rich Stay Rich and the Poor Stay Poor." Working paper. Duke University, Durham, NC.

Bowman, Douglas and Shilpa Lele-Pingle. 1997. "Buyer Behavior in Business-to-Business Services: The Case of Foreign Exchange." International Journal of Research in Marketing 14 (5): 499-508.

Collopy, Fred. 1996. "Biases in Retrospective Self-Reports of Time Use: An Empirical Study of Computer Users." Management Science 52 (5): 758-767.

Crosby, Lawrence A. and Nancy Stephens. 1987. "Effects of Relationship Marketing on Satisfaction, Retention, and Prices in the Life Insurance Industry." Journal of Marketing Research 24 (November): 404-411.

Dick, Alan S. and Kunal Basu. 1994. "Customer Loyalty: Toward an Integrated Conceptual Framework." Journal of the Academy of Marketing Science 22 (2): 99-113.

Gilly, Mary C. and Betsy D. Gelb. 1982. "Post-Purchase Customer Processes and the Complaining Customer." Journal of Customer Research 9 (December): 323-328.

Hogarth, R. and H. Einhorn. 1992. "Order Effects in Belief Updating: The Belief-Adjustment Model." Cognitive Psychology 24:1-55.

Inman, J. Jeffrey, James S. Dyer, and Jianmin Jia. 1997. ”A Generalized Utility Model of Disappointment and Regret Effects on Post-Choice Valuation.” Marketing Science 16 (2): 97-111.

Johnson, Michael D. 1984. "Customer Choice Strategies for Comparing Noncomparable Alternatives." Journal of Customer Research 11 (December): 741-753.

_ and Seigyoung Auh. 1999. "Compatability Effects in Evaluations of Customer Satisfaction and Loyalty." International Journal of Research in Marketing 17 (4).

Jones, Thomas O. and W. Earl Sasser Jr. 1995. "Why Satisfied Customers Defect." Harvard Business Review 73 (6): 89-99.

Judge, G. G., R. C. Hill, W. E. Griffiths, H. Lutkepohl, and T. C. Lee. 1988. Introduction to the theory and practice of econometrics. 2nd ed. New York: John Wiley.
Keaveney, Susan M. 1995. "Customer Switching Behavior in Service Industries: An Exploratory Study." Journal of Marketing 59 (April): 71-82.

Krishnamurthi, Lakshman, Tridib Mazumdar, and S. P. Raj. 1992 "Asymmetric Response to Price in Consumer Brand Choice and Purchase Quantity Decisions.” Journal of Consumer Research 19 (December): $387-400$.

LaBarbera, Priscilla A. and David Mazursky. 1983. "A Longitudinal Assessment of Customer Satisfaction/Dissatisfaction: The Dynamic Aspect of the Cognitive Process." Journal of Marketing Research 20 (November): 393-404

Loomes, Graham and Robert Sugden. 1982. "Regret Theory: An Alternative Theory of Rational Choice Under Uncertainty." The Economic Journal 92 (December): 805-824.

Luce, Mary Frances. 1998. "Choosing to Avoid: Coping With Negatively Emotion-Laden Customer Decisions." Journal of Customer Research 24 (March): 409-424.

Mazumdar, Tridib and Purushottam Papatla. 1995. "Loyalty Differences in the Use of Internal and External Reference Prices." Marketing Letters 6 (March): 111-122.

Morwitz, Vicki. 1997. "Why Customers Don't Always Accurately Predict Their Own Future Behavior." Marketing Letters 8 (1): 57-70.

_ and David Schmittlein. 1992. "Using Segmentation to Improve Sales Forecasts Based on Purchase Intent: Which "Intenders' Actually Buy." Journal of Marketing Research 29 (November): 391-405.

Nowlis, S. M. and Itamar Simonson. 1997. "Attribute-Task Compatibility as a Determinant of Customer Preference Reversals." Journal of Marketing Research 34:205-218.

O'Brien, Louise and Charles Jones. 1995. "Do Rewards Really Create Loyalty?" Harvard Business Review 73 (May-June): 75-82.

Oliver, Richard. 1980. "A Cognitive Model of the Antecedents and Consequences of Satisfaction Decisions." Journal of Marketing Research 17:460-469.

Reichheld, Fredrick F. and W. Earl Sasser. 1990. "Zero Defections: Quality Comes to Services." Harvard Business Review 14 (March): 495-507.

Riley, F. Dall'Olmo, A.S.C. Ehrenberg, S. B. Castleberry, T. P. Barwise, and N. R. Barnard. 1997. "The Variability of Attitudinal RepeatRates." International Journal of Research in Marketing 14 (5): 437-450.

Rust, Roland T., Jeffrey Inman, and Anthony Zahorik. 1995. “A Bayesian Model of Quality and Customer Retention.” Working Paper. Vanderbilt University, Nashville, TN

_ and Richard Metters. 1996. "Mathematical Models of Service." European Journal of Operational Research 91 (June): 427-439.

Schmittlein, David C., Donald G. Morrison, and Richard Colombo. 1987. "Counting Your Customers: Who Are They and What Will They Do Next." Management Science 33 (January): 1-24.

and Robert A. Peterson. 1994. "Customer Base Analysis: An Industrial Purchase Process Application.” Marketing Science 13 (Winter): 41-67.

Schul, Yaacov and Miriam Schiff. 1993. "Measuring Satisfaction With Organizations." Public Opinion Quarterly 57 (4): 536-551.

Simonson, Itamar. 1992. "The Influence of Anticipating Regret and Responsibility on Purchase Decisions." Journal of Customer Research 19:105-118

and Amos Tversky. 1992. "Choice in Context: Tradeoff Contrast and Extremeness Aversion." Journal of Marketing Research 29 (August): 281-295.

Solnick, Sara J. and David Hemenway. 1992. "Complaints and Disenrollment at a Health Maintenance Organization." Journal of Customer Affairs 26 (1): 90-103.

Thaler, Richard. 1985. "Mental Accounting and Customer Choice." Marketing Science 4 (Summer): 199-214.

Tobin, James. 1958. "Estimation of Relationships for Limited Dependent Variables." Econometrica 31:24-36.

Uncles, Mark and Gilles Laurent. 1997. "Editorial, Special Issue on Loyalty." International Journal of Research in Marketing 14: 399-404.

Zahorik, Anthony J. and Roland T. Rust. 1992. "Modeling the Impact of Service Quality on Profitability: A Review." In Advances in Services Marketing, Vol 1. Eds. T. Swartz and R. Oliver. Greenwich, CT: JAI, 247-276. 


\section{ABOUT THE AUTHORS}

Ruth N. Bolton is Ruby K. Powell Professor of Marketing in the Michael F. Price College of Business at the University of Oklahoma. Her current research is concerned with high-technology services sold to business-to-business customers. Her most recent work in this area studies how organizations can grow the value of their customer base through customer service and support. She previously held positions at the University of Maryland, GTE Laboratories Incorporated, the University of Alberta, CarnegieMellon University, and the University of British Columbia. Her business experience involves a variety of consulting projects addressing services marketing, customer satisfaction, and quality management issues in the telecommunications and information services industries. Her earlier published research investigates how organizations' customer service and pricing strategies influence customer satisfaction and loyalty. She received her B.Comm. with honors from Queen's University at Kingston and her M.Sc. and Ph.D. from Carnegie-Mellon University. She currently serves on the editorial boards of the Journal of Retailing, the Journal of Marketing, Marketing Science, Marketing Letters, the Journal of Marketing Research, and the Journal of Service Research. She has published articles in these and other journals.

P. K. Kannan is Safeway Fellow and Associate Professor of Marketing in the Smith School of Business at the University of Maryland. He received his Ph.D. from Purdue University. His research and teaching interests are in electronic commerce, and marketing research and modeling. His research on competitive market structures, consumers' loyalty, variety seeking, and reinforcement behaviors, and the effects of promotions on competition have appeared in Marketing Science, Management Science, Journal of Business Research, and International Journal of Re- search in Marketing. His current interests center on the marketing of information products such as market research, software, and data products using electronic channels such as the Internet covering issues of strategy, pricing, and product reliability. Articles focusing on these issues have appeared or are forthcoming in Communications of the ACM, International Journal of Electronic Commerce, and the Handbook of Electronic Commerce. $\mathrm{He}$ is a member of the American Marketing Association, the Institute of Management Science, and the American Statistical Association. He has corporate experience with Tata Engineering and Ingersoll-Rand and has consulted for companies such as Frito-Lay, Pepsi Co, SAIC, and Fannie Mae. Prior to joining the University of Maryland, he was on the faculty of the University of Arizona, Tucson.

Matthew D. Bramlett is a doctoral candidate in the Department of Sociology and a faculty research assistant in the Department of Marketing at the University of Maryland, College Park. His dissertation is an event history analysis of the effects of children on the stability of marriages and cohabitations. His current research focuses on high-technology services sold to business-to-business customers. His other research interests include the commodification of sports and the exploitation of the consumer in professional sports, and the fertility effects of family planning programs in developing countries over time. He is a member of the Population Association of America and a member of the Family, Sociology of Population, and Race, Gender, and Class sections of the American Sociological Association. His work on the exploitation of the consumer in the National Football League will be published as a chapter in the forthcoming book Consumers, Commodification and Media Culture: Perspectives on the New Forms of Consumption, edited by Mark Gottdiener, University of New York at Buffalo. 